The American Journal of Political Science Law and Criminology

(ISSN - 2693-0803)

VOLUME 04 ISSUE 01 Pages: 109-114

SJIF IMPACT FACTOR (2020: 5. 453) (2021: 5. 952)

OCLC - 1176274523 METADATA IF - 7.659

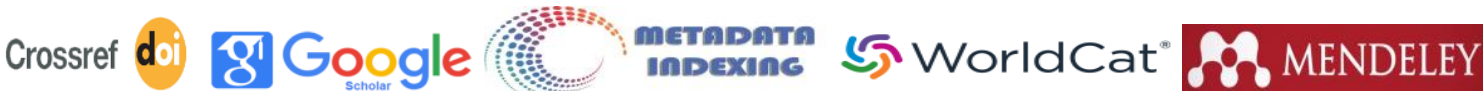

Research Article

\title{
PROSPECTS FOR THE IMPLEMENTATION AND LEGAL REGULATION OF ISLAMIC FINANCIAL PRODUCTS IN THE REPUBLIC OF UZBEKISTAN
}

Journal Website: https://theamericanjou rnals.com/index.php/ta jpslc

Copyright: Original content from this work may be used under the terms of the creative commons attributes 4.0 licence.

\author{
Submission Date: January 09, 2022, Accepted Date: January 20, 2022, \\ Published Date: January 30, 2022 \\ Crossref doi: https://doi.org/10.37547/tajpslc/Volumeo4lssue01-16
}

Bozarov Shavkat Tadjibaevich

Philosophy Doctor in Law, Leasing Association of Uzbekistan, Lawyer, Uzbekistan

\section{ABSTRACT}

This article analyzes the implementation of Islamic financial services in the Republic of Uzbekistan based on the characteristics of Islamic financial products and the positive impact of these financial products on the entire economy of the Republic of Uzbekistan.

\section{KEYWORDS}

Sharia, principles of Islamic finance, riba, garar, maysir, risk sharing, law.

\section{INTRODUCTION}

For decades, there has been a steady increase in the volume of Islamic financial services around the world. Islamic financial products are actively being introduced in the USA, Great Britain, Germany, France and other non-Islamic countries. Major financial groups led by multinational banks are evaluating the benefits of Islamic financial products and are taking steps to create appropriate structures to offer their services in this fast-growing segment of the financial market.The Republic of Uzbekistan, whose leadership firmly adheres to the course of creating a modern market economy, has great potential for the development of Islamic finance in its territory. More than $90 \%$ of the population of the republic are Muslims and there is a real need in the country for the introduction of Islamic financial products. Most banks and other financial 
The American Journal of Political Science Law and Criminology (ISSN - 2693-0803)

VOLUME 04 ISSUE 01 Pages: 109-114

SJIF IMPACT FACTOR (2020: 5 - 453) (2021: 5. 952)

OCLC - 1176274523 METADATA IF - 7.659

institutions, such as insurance and leasing companies, are ready to offer their services based on the principles of Islamic finance, if an appropriate legal and regulatory framework is created.

Highly assessing the potential of Islamic financial products for the further development of the financial system and ensuring its stability due to the real nature of Islamic financial products, and responding to the high demand of society for Islamic financial products, the President of the Republic of Uzbekistan in his message to the Oliy Majlis of the Republic of Uzbekistan noted that the time has come for creating a legal framework for the implementation of Islamic financial products with the involvement of experts from the Islamic Development Bank and other international financial institutions [1].

The lack of a legal framework is the main barrier to the introduction of financial instruments based on the principles of Islamic finance. However, before considering the issue of adopting legislation and creating a regulatory framework for the implementation of Islamic financial products and the functioning of Islamic financial institutions, let us consider the essence of Islamic financial products and their distinctive features from financial services offered by the so-called "traditional" financial institutions.

Any institutional sector functions only if there are rules and regulations that are designed to regulate it. The rules governing the way of life of Muslims, including in the field of business and financial activities, are contained in the set of rules and principles of Islamic law - Sharia.

These rules and principles have the following four sources.
The first source is the holy book of the Koran as a true and unchanging source of spiritual knowledge for all Muslims. The Koran consists of Divine revelations, which are a guide for all followers of the Prophet Muhammad.

The hadith is the second source of these rules and regulations. They form the basis of the Sunnah and are short stories about episodes from the life of the Prophet Muhammad, about his sayings and actions in various life situations.

The third source of Sharia is "ijma" as a set of decisions worked out by authoritative Islamic scholars mujtahids on specific issues and cases from the life of the faithful for a specific issue or case.

The fourth source - "qiyas" is a judgment by analogy and the development of new decisions by the mujtahids on the basis of the precedent described in the Quran or hadith

The provisions of the Sharia, based on the Qur'an and hadiths, contain the absolute truth and the undeniable fundamental doctrine of Islam, their reliability is not subject to doubt under any circumstances. ljma and qiyas, also known as "furu", are offshoots of Sharia law.

Based on the provisions contained in these four sources, Muslim economists and legal scholars over the past few decades have formulated, and government bodies almost throughout the world have adopted rules for conducting financial activities that meet the requirements of Sharia. There is a general consensus among Islamic (and traditional) scholars that Islamic finance should be based on the following principles.

1. Ban on riba. According to A.R. Rakhmanov, today one of the main issues of international Islamic 
The American Journal of Political Science Law and Criminology

(ISSN - 2693-0803)

VOLUME 04 ISSUE 01 Pages: 109-114

SJIF IMPACT FACTOR (2020: 5. 453) (2021: 5. 952)

OCLC - 1176274523 METADATA IF - 7.659

financial forums is the ban on charging interest surcharges due to the fact that in the 21st century there is not a single Muslim country that does not carry out credit transactions with non-Muslim states [2].

The Islamic financial system prohibits riba (surplus), which is understood as any unjustified capital increase in a loan or in the implementation of a trade transaction. In other words, any predetermined rate that depends on the terms and size of the loan and does not depend on the success of the investment is called riba and is prohibited.

Most Islamic scholars refer to the concept of riba not only as high, usurious, but also any loan interest. This prohibition is justified by the notions of social justice, equality and property rights. Islam encourages profit, but condemns the use of interest for profit, since such activity does not lead to the creation of a product and cannot increase the welfare of society. Social justice requires that borrowers and lenders receive compensation or losses on an equal footing and that the process of accumulation and creation of wealth in the economy reflects the real contribution of economic agents to economic development.

It should be noted that riba as an unreasonable increase in money capital has been condemned by mankind since ancient times. M.Z.Gibatulin and T.M.Vakhitov, having studied the economic views of the ancient Greek philosophers, note that "The general feature of the economic thought of the Ancient world is the desire to preserve the priority of the natural economy, to condemn trade and usurious operations from the standpoint of morals, morality and ethic" [3].

2. Sharing risk. Due to the prohibition on charging interest, those who offer money on credit become investors, not creditors. The owner of financial capital and the entrepreneur share the risks in order to share the benefits. Any financial institution operating on the basis of Sharia principles must be prepared to share with a partner both future gains and profits, as well as losses and losses. An Islamic bank is always ready to assume the risks that arise when their clients use the financial resources presented to them. A leasing company that provides services in "ljarah" cannot transfer to the lessee all the risks associated with the operation of the leased object, as provided for in the leasing legislation governing traditional leasing.

3. Prohibition of garar. Garar is traditionally understood as the uncertainty of the main terms of the deal. Honest and fair business activity involves full clarification of all the key points of the transaction. Although the current civil legislation of most modern states, including Uzbekistan, contains provisions regarding the essential conditions of almost all agreements encountered in practice, there is a potential for a transaction to be recognized as not complying with the principles of Islamic finance due to garar, which requires a careful analysis of the Islamic financial product, especially before it implementation.

4. Money as "potential" capital. Money is considered as "potential" capital, that is, it becomes real capital only when it is invested in production activities. Moreover, money cannot be regarded as a commodity. Sharia condemns hoarding and endorses the constant use of free money in trade and production.

5. Prohibition of speculative behavior, "maysir". The Islamic financial system prohibits activities characterized by great uncertainty (for example, gambling). Due to the existence of "maysir" in the Islamic financial system, it is extremely difficult to 
The American Journal of Political Science Law and Criminology

(ISSN - 2693-0803)

VOLUME 04 ISSUE 01 Pages: 109-114

SJIF IMPACT FACTOR (2020: 5. 453) (2021: 5. 952)

OCLC - 1176274523 METADATA IF - 7.659

spread financial derivatives, transactions with which are inherent in significant risk.

6. The inviolability of contracts. Islam preaches the fulfillment of contractual obligations as the most important obligation of the parties to the transaction. This principle is in line with the ancient Roman principle of Pacta Sunt Servanta, according to which a concluded contract is a law for two.

As correctly notes E.A.Baydaulet, unlike the traditional financial system, the Islamic financial system has a clear social orientation in accordance with moral and ethical principles [4]. Islamic economics has been considered by scholars and theologians of the Muslim East since the heyday of the Caliphate (Al-Ghazali, Al-Farabi, Ibn Taymiyyah) and is understood as part of a social order, the laws of which were determined by a divine plan and transmitted to mankind through a chain of prophets: Abraham, Moses, Jesus and in the final teaching on the universe of the Prophet Muhammad.

Social orientation presupposes the main goal of economic development - ensuring social justice in the distribution of the results of economic activity. The means to achieve this goal are the development of the real sector of the economy and socio-economic progress. Along with this, theologians and economists emphasize the special role of spiritual ethics and morality, its inherent ability to protect economic activity from abuse and lawlessness.

One of the most important characteristics of Islamic finance is that it is real asset finance. The usual traditional concepts of finance are that banks and financial institutions only buy and sell money and monetary obligations. And Islam does not recognize money as a commodity. Money has no intrinsic value, it is only a medium of exchange, it is the monetary equivalent of a good or service. Profit is generated when something of its own value is sold for money or when different currencies are exchanged for one another.

The profit received as a result of a credit and debt operation with money (in the same currency) or with securities replacing them is monetary value added, therefore, is prohibited. Thus, unlike conventional financial institutions, Islamic finance is always based on real assets, in the process of circulation of which real added value is formed. Let us consider this provision using examples of certain Islamic financial instruments.

"Salam" and "istisna" financial advance financing instruments serve to create real assets. The client of a financial institution in the operation of salam uses the received monetary resources in agriculture to grow the crop, and after selling it, shares his profit with the financier. In the case of istisna, financing is directed to the production of infrastructure assets, and for the delayed sale of them, the investor, along with his money, receives a fixed profit.

"ljarah" and "murabaha" instruments are also fully asset-backed, and financing through these instruments is clearly different from interest-based financing for the following reasons:

- In traditional financing, the financier gives money to his client as an interest-bearing loan, after which he has nothing to do with how the funds are used by the client. In the case of murabaha, on the contrary, the financier does not provide cash to the client;

- One of the main requirements for the validity of murabaha is that the goods are purchased by the financier, which means that he takes the risk of the goods before selling them to the client. The profit declared by the financier is a reward for the risk that he takes on. Such a transaction is not an interest-based loan; 
The American Journal of Political Science Law and Criminology

(ISSN - 2693-0803)

VOLUME 04 ISSUE 01 Pages: 109-114

SJIF IMPACT FACTOR (2020: 5. 453) (2021: 5. 952)

OCLC - 1176274523 METADATA IF - 7.659

- With a loan that brings interest income, the amount to be repaid by the borrower continues to increase over time. In murabaha, on the other hand, the sale price is fixed after negotiation. As a result, even if the buyer (bank client) does not pay on time, the seller (bank) cannot ask for a higher price due to the delay in resolving fees. This is due to the fact that there is no concept of time measurement of money in Sharia;

- Also in the case of leasing, financing is carried out through the provision of operating assets that have the right to use. ljarah has a number of differences from traditional leasing, which, in fact, are predetermined by the principles of Sharia [5]. The risk associated with the purchase and further lease of property is borne by the lessor/financier throughout the lease term, in the sense that if the leased asset is completely destroyed and without the presence of facts of misuse or negligence on the part of the lessee, then the financier/lessor will bear the losses. The client, in this case, is jointly and severally liable at the expense of the provided material security.

As you can see from the above, each type of Islamic finance creates real added value. Ordinary bank loans create additional money supply, which multiplies outside the real turnover of a smaller volume. This gap between the money supply and the real sector increases inflation, due to the mutual imbalance, monetary units are devalued, which automatically affects the rise in prices for raw materials and services, expressed in increasingly cheaper "goods", namely, paper unsecured money.

Currently, in the current legislation of the Republic of Uzbekistan, there are various gaps and obstacles that make it impossible to provide Islamic financial services. We are talking about both the lack of a legal framework for key aspects in the activities of Islamic financial instruments, for example, regulating the activities of Sharia councils and Sharia experts on giving an opinion on the compliance of a financial product with the requirements of Sharia (fatfah) or the audit of Islamic financial products, as well as on legal norms, creating a barrier to Islamic financial products. In particular, Article 22 of the Law of the Republic of Uzbekistan "On Leasing" provides that lease payments represent reimbursement of the value of the leased object and the interest income of the lessor, which directly contradicts the Riba prohibition principle, and Article 19 imposes on the lessee all property risks associated with the leased object, which also contradicts the requirement of the Sharia principle on the sharing of risks between partners [6]. Article 60 of the Tax Code of the Republic of Uzbekistan also refers to the interest income of the lessor (lessor) [7].

Therefore, the introduction of Islamic financial products should be carried out on the basis of the adoption of regulatory legal acts, which, firstly, create a legal basis for certain types of activities inextricably linked with the provision of Islamic financial services, such as activities for the examination of the future Islamic financial product according to the principles of Sharia and Islamic audit, and secondly, remove existing barriers to Islamic financial products.

For the above purposes, the author proposes the adoption of a separate law on the fundamentals of Islamic finance in the Republic of Uzbekistan, and on the basis of this law (it is possible and at the same time with this law), it is proposed to amend and supplement existing normative legal acts, such as the Civil Code, in Laws "On Banks and Banking Activities", "On Insurance”, "On Leasing”, etc.

The introduction of Islamic financial products will have a positive impact not only in terms of meeting the 
The American Journal of Political Science Law and Criminology (ISSN - 2693-0803)

VOLUME 04 ISSUE 01 Pages: 109-114

SJIF IMPACT FACTOR (2020: 5 - 453) (2021: 5. 952)

OCLC - 1176274523 METADATA IF - 7.659

Crossref dol g' Google

6. The Law of the Republic of Uzbekistan "On Leasing". Statements of the Oliy Majlis of the Republic of Uzbekistan. 1999. No. 5 Art. 108.

7. Tax Code of the Republic of Uzbekistan. T. Adolat. 2020.

financial market is resistant to various financial crises and shocks, not only of a national but also of an international scale. In addition, the introduction of Islamic financial products will stimulate many international financial institutions and financial institutions in modern Islamic states to invest large financial resources in the economy of Uzbekistan. Also, the creation of a legal framework will stimulate internal investment processes.

Thus, for the introduction of Islamic financial products in the Republic of Uzbekistan, the author proposes the adoption of a special law of the Republic of Uzbekistan on the foundations of Islamic financial activity and the introduction of amendments and additions to the existing sectoral regulatory legal acts. The introduction of Islamic financial products will have a positive impact on the stability of the republic's financial system, will stimulate both the attraction of foreign investment and domestic investment.

\section{REFERENCES}

1. Message from the President of the Republic of Uzbekistan Shavkat Mirziyoyev to the Oliy Majlis. 2020.https: //president.uz/ru/lists/view/4057.

2. Rakhmanov A.R., Ruziev R.Zh., Rakhmanov A.R. Islamic law. Textbook. BSPU. Ufa. 2010. P.224

3. Gibadullin M.Z., Vakhitova T.M. Fundamentals of Islamic economics: theory and practice of management. Kazan. TGSPU. 2009. P.8.

4. Baydaulet E.A. Fundamentals of Ethical (Islamic Finance). Tutorial. Baydaulet. E.A. 2014. P.25.

5. Mufti Muhammad Taqi Usmani. An introduction to Islamic Finance. 2002. P.111-126. 